\title{
Failure Modes and Effects Analysis (FMEA) for evaluation of a sugarcane machine failure
}

\author{
Hilma Raimona Zadry ${ }^{1, *}$, Dendi Adi Saputra ${ }^{2}$, Agung Budiman Tabri ${ }^{1}$, Difana Meilani ${ }^{1}$, \\ and Dina Rahmayanti ${ }^{1}$ \\ ${ }^{1}$ Department of Industrial Engineering, Faculty of Engineering, Universitas Andalas, Limau Manis, \\ 25163 Padang, Indonesia \\ ${ }^{2}$ Department of Mechanical Engineering, Faculty of Engineering, Universitas Andalas, Limau Manis, \\ 25163 Padang, Indonesia
}

\begin{abstract}
The Failure Modes and Effects Analysis (FMEA) method has been widely recognized as a tool that systematically identifies the consequences and failures of the system or process, and reduces or eliminates the chances of the failure. This study applies that method to evaluate the causes of failure in the use of sugarcane machine that have been designed in the previous studies. FMEA approach anticipated the failures at the design stage, so that a more reliable and ergonomic design can be produced for future sugarcane machine. The potential failure identified from the machine consists of capacity issues, machine maintenance, preliminary treatment, and procedures of use. The study found that capacity issues are the priority problems that cause the machine failure. Then, this study proposed some actions to reduce the risk priority number (RPN) on 12 failures.
\end{abstract}

\section{Introduction}

Indonesia is an area with abundant natural resources, making it known as an agricultural country [1]. One of the high potential agricultural sectors and continuously pursued in improving the national economy is the cane commodity of West Sumatera [2]. One effort undertaken to improve the productivity of sugarcane processing is designing a sugarcane machine for producing brown sugar. This machine is used to replace the traditional sugarcane process using buffalo power. Previous research has designed and made a prototype of a sugarcane machine with the application of ergonomic principles [3]. However, in its application, still found the failure of the machine operation (breakdown). The results of a brief interview with a sugarcane machine operator indicates that the roller and gear of the machine is no longer usable. Therefore, it is necessary to evaluate the use of sugarcane machine designed by Zikri [3] and propose suggestions for improvement of the failure that already occurred. This research aims to evaluate the causes of failure of the Zikri [3] sugarcane machine and provide recommendation improvement for the design.

\footnotetext{
* Corresponding author: hilma@eng.unand.ac.id
} 
Failure modes and effects analysis (FMEA) is a tool that systematically identifies the consequences and failures of the system or process, and reduces or eliminates the chances of failure [4]. FMEA is a living document used to prevent and anticipate the occurrence of failure [5]. FMEA is the best nominee for reliability analysis at the design stage, is precise and has been used for many power generation engineering systems [6].

The following is the process in designing FMEA [7]:

1. Identify potential products and relate to ways of process failure

2. Estimate potential consumer effects caused by failure

3. Identify possible causes of the assembly process and identify variables in the process that are useful for focusing on controls to reduce failure or detect failures

4. Develop a list of potential ratings and means of failure, this establishes the process system as a consideration for corrective action

5. Document the results and the production or assembly process.

\section{Methods}

Several methods have been commonly used to evaluate the product failure such as FMEA [6, 8-10], fault tree analysis (FTA) [11-13], and root cause analysis [14-16]. This study used FMEA to evaluate the potential failure of sugarcane machine. The FMEA assists in answering questions such as what might cause problems, how to avoid problems arising, and so on. FMEA is considered most appropriate with this research because the analysis is done when the exact cause of potential failure is not known.

Data collection in the form of machine failures is conducted through direct interviews with operators and machine users. Further investigation of the causes of failure experienced by sugarcane machine using a fishbone diagram. The results obtained from fishbone diagram analysis are used as guidance in giving the proposed action to improve the sugarcane machine design using FMEA method. Ten steps taken in identifying potential failures using the FMEA method are as follow [17]:

1. Perform an overall review of the process or product to be identified

2. Brainstorm or create a list of potential failure models

3. Create a list of potential effects of each failure model

4. Prepare a severity ranking for each potential cause of failure

5. Prepare an occurrence ranking for each failure model

6. Compile detection rates for each failure model

7. Calculate Risk Priority Number (RPN) for each failure model, with the following equation:

$$
R P N=\text { Severity } x \text { Occurance } x \text { Detection }
$$

8. Prioritize failure model for giving proposed actions

9. Provide proposed actions to reduce high risk failure model

10. Recount the RPN after giving the proposed action.

\section{Results and Analysis}

A preliminary survey of machine-user interviews was conducted to find information on potential causes of the machine failure. The results of interviews obtained some machine failures: (1) Roller and gear was not working; (2) The maximum capacity of the cane during the milling process was not determined; (3) The machine was not cleaned after use; (4) The operator did not set the clearance roller when grinding the cane; (5) The working environment is very dirty; (6) There was no standard operating procedure for machine use 
and maintenance; (7) Bagasse from milling piled around the machine; (8) No preliminary treatment of sugarcane; (9) Machine operating time was too long; (10) Machine coolant was not available yet. These problems are then grouped into four categories of failure, namely capacity issues, machine maintenance, preliminary treatment, and machine use procedures. Then, a fishbone diagram was utilized to investigate the potential failure of the machine for each category of failure. Figure 1 shows the fishbone diagram for capacity problems.

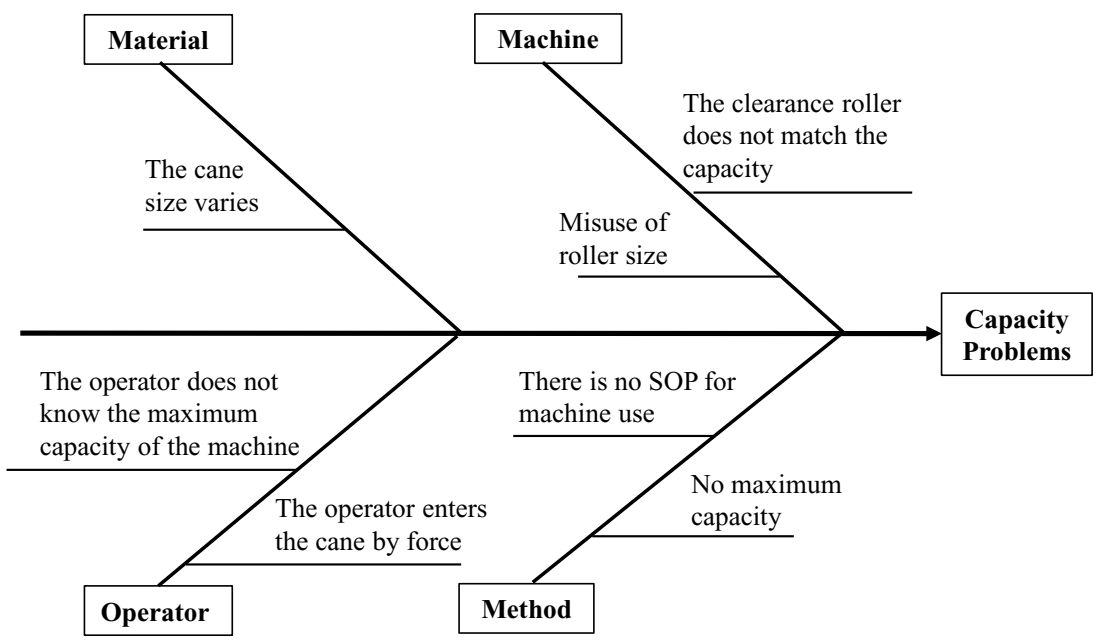

Fig. 1. Fishbone diagram for capacity problems.

The investigation results using the fishbone diagram were then further analysed to find the model definition, cause, and impact of potential machine failure. The analysis was conducted through brainstorming with four experts from universities and industries, so it was found 37 problems of failure causes. The next step was to calculate and sort the RPN value based on the severity, occurrence, and detection values obtained from expert opinion. The proposed action was given to the $30 \%$ of the highest failure causes (the highest RPN value), which was 12 points of failure.

The risk priority matrix was then constructed to determine the degree of risk of an incident based on its impact and probability. The RPM results show that there are two potential failures at the extreme level, i.e., the difference in the size of the top and the bottom roller (P1) and the operator does not know the specification of the machine in detail (P5). Extreme level means a level with a very high risk status. Things that might happen at these levels include objectives and outcomes that are not achieved, resulting in large financial losses. Overall, the proposed action for the 12 priority failures of this sugarcane machine are shown in Table 1.

\section{Conclusions}

This research concludes that FMEA has successfully applied to investigate the failure of sugarcane machine. The analysis found that there are four categories of potential failures in sugarcane machines such as capacity problems, machine maintenance, preliminary treatment, and machine use procedures. Capacity issues are the priority problems that cause the sugarcane machine failures. Potential failure at the extreme level is the difference between the size of the top roller and the bottom roller and the operator that does not know the machine specification in detail. A suggestion for future studies would be to realize the 
proposed actions against the potential failure so that the productivity of cane processing can be improved.

Table 1. Proposed actions for sugarcane machine failures.

\begin{tabular}{|c|c|c|c|c|c|c|c|}
\hline No. & $\begin{array}{l}\text { Priority } \\
\text { Failures }\end{array}$ & Code & Severity & $\begin{array}{c}\text { Occur- } \\
\text { ance }\end{array}$ & $\begin{array}{l}\text { Detect- } \\
\text { ion }\end{array}$ & RPN & Proposed Actions \\
\hline 1 & $\begin{array}{c}\text { The size } \\
\text { difference } \\
\text { between the top } \\
\text { and the bottom } \\
\text { roller }\end{array}$ & P1 & 138,0 & 123,0 & 98,0 & 1663452,0 & $\begin{array}{l}\text { The length of the } \\
\text { bottom roller is changed } \\
\text { to } 30 \mathrm{~cm} \text { according to } \\
\text { the length of the top } \\
\text { roller }\end{array}$ \\
\hline 2 & $\begin{array}{c}\text { The operator } \\
\text { does not know } \\
\text { the specification } \\
\text { of the machine in } \\
\text { detail }\end{array}$ & P5 & 125,0 & 132,0 & 66,0 & 1089000,0 & $\begin{array}{c}\text { Provide detailed } \\
\text { machine specifications } \\
\text { around the machine or } \\
\text { work area }\end{array}$ \\
\hline 3 & $\begin{array}{l}\text { SOP for machine } \\
\text { use has not been } \\
\text { designed }\end{array}$ & P35 & 72,0 & 100,0 & 100,5 & 723600,0 & $\begin{array}{l}\text { Design a complete SOP } \\
\text { of machine usage }\end{array}$ \\
\hline 4 & $\begin{array}{c}\text { The machine is } \\
\text { not cleaned after } \\
\text { use }\end{array}$ & P16 & 85,0 & 121,0 & 66,0 & 678810,0 & $\begin{array}{l}\text { Cleaning process to } \\
\text { follow the instructions } \\
\text { and rules that exist in } \\
\text { the SOP }\end{array}$ \\
\hline 5 & $\begin{array}{l}\text { There is no } \\
\text { maximum } \\
\text { capacity set for } \\
\text { each sugarcane } \\
\text { milling process }\end{array}$ & P35 & 118,0 & 125,5 & 44,5 & 659000,5 & $\begin{array}{l}\text { Establish a maximum } \\
\text { capacity of each mill } \\
\text { process for five stems of } \\
\text { sugarcane of } 5-6 \mathrm{~cm}\end{array}$ \\
\hline 6 & $\begin{array}{l}\text { There is no } \\
\text { preliminary } \\
\text { treatment of } \\
\text { sugarcane before } \\
\text { it is milled by the } \\
\text { machine }\end{array}$ & $\mathrm{P} 27$ & 81,0 & 78,5 & 96,0 & 610416,0 & $\begin{array}{c}\text { Tapered sugarcane } \\
\text { before being processed } \\
\text { by machine or } \\
\text { designing sugarcane } \\
\text { splitter }\end{array}$ \\
\hline 7 & $\begin{array}{c}\text { Machine coolant } \\
\text { was not available } \\
\text { yet }\end{array}$ & P37 & 86,0 & 58,0 & 119,0 & 593572,0 & $\begin{array}{l}\text { Provide machine } \\
\text { cooling tool }\end{array}$ \\
\hline 8 & $\begin{array}{l}\text { The operator } \\
\text { does not know or } \\
\text { forgot how to set } \\
\text { the roller to fit } \\
\text { the capacity }\end{array}$ & P4 & 115,5 & 126,5 & 40,5 & 591735,4 & $\begin{array}{l}\text { Provide instructions for } \\
\text { roller arrangement to } \\
\text { make it easier for the } \\
\text { operator when milling } \\
\text { the cane } 3 \mathrm{~cm} \text { in size }\end{array}$ \\
\hline 9 & $\begin{array}{l}\text { Production } \\
\text { planning is } \\
\text { incompatible } \\
\text { with machine } \\
\text { capability }\end{array}$ & P6 & 102,5 & 66,5 & 81,5 & 555524,4 & $\begin{array}{l}\text { Make a daily production } \\
\text { planning as much as } \\
134-154 \mathrm{~kg} \text { of } \\
\text { sugarcane to get } 100 \mathrm{~kg} \\
\text { of sugarcane juice }\end{array}$ \\
\hline 10 & $\begin{array}{l}\text { Limited working } \\
\text { hours }\end{array}$ & P8 & 98,0 & 105,0 & 53,0 & 545370,0 & $\begin{array}{l}\text { Optimize performance } \\
\text { and work shift division } \\
\text { into one or two hours }\end{array}$ \\
\hline 11 & $\begin{array}{l}\text { Engine capacity } \\
\text { is highly } \\
\text { dependent on the } \\
\text { size of the cane } \\
\text { diameter } \\
\end{array}$ & $\mathrm{P} 10$ & 90,5 & 73,0 & 77,5 & 512003,8 & $\begin{array}{l}\text { Adds a sugarcane } \\
\text { component that helps } \\
\text { the cane to easily fit } \\
\text { into the roller }\end{array}$ \\
\hline 12 & $\begin{array}{c}\text { The operator } \\
\text { works in a hurry }\end{array}$ & P7 & 104,0 & 84,5 & 58,0 & 509704,0 & $\begin{array}{l}\text { Monitoring the } \\
\text { operator's work }\end{array}$ \\
\hline
\end{tabular}

This study is partly funded by Ministry of Research, Technology, and Higher Education Republic of Indonesia through PTUPT No. 30/UN.16.17/PP.UPT/LPPM/2017. 


\section{References}

1. Soekartawi, Pengantar agroindustri (Raja Grafindo Persada, Jakarta, 2001)

2. Hajisman, Analisis Perbandingan Tingkat Keuntungan Usaha Pengolahan Gula Merah (Gulo Saka) Antara Petani Kilang Tradisional dengan Petani Kilang Mekanis di Kenagarian Bukik Batabuah Kecamatan Canduang Kabupaten Agam, (Universitas Andalas, Padang, 2012)

3. A. Zikri, Perancangan Ulang Mesin Pengilang Tebu Sebagai Alat Penghasil Bahan Baku Saka Dengan Pertimbangan Aspek Ergonomi, (Universitas Andalas, Padang, 2016)

4. H. Liu, L. Liu, N. Liu, Expert Syst. Appl, 40 (2013)

5. L.H. Chen and W.C. Ko,, Appl. Math. Mode, 33 (2007)

6. H. Arabian-Hoseynabadi, H. Oraee, P.J. Tavner, Int. J. Elec. Power, 32 (2010)

7. L.K. Kevin, Manajemen Dan Prinsip Pemasaran Edisi Dua Belas Jilid 1 (Erlangga, Jakarta, 2001)

8. I. Setyadi, Analisis Penyebab Kecacatan Produk Celana Jeans Dengan Menggunakan Metode Fault Tree Analisis (FTA) dan Failure Mode and Effect Analysis (FMEA) di CV Fragile Din Co (Universitas Andalas, Padang, 2013)

9. M.A. Rosen, J.B. Sampson, E.V. Jackson Jr, R. Koka, A.M. Chima, O.U. Ogbuagu, M.K. Marx, M. Koroma, B.H. Lee, Br., J. Anaesth, 113 (2014)

10. B. Salah, O. Janeh, T. Bruckmann, B. Noche,, IFAC-PapersOnLine, 48 (2015)

11. T. Ferdiana and I. Priyadhitama, Analisis Defect Menggunakan Metode Fault Tree Analysis (FTA) Berdasarkan Data Ground Finding Sheet (GFS) PT. GMF Aeroasia (Universitas Sebelas Maret, Surakarta, 2011)

12. E. Ruijters and M. Stoelinga, Computer Science Review, 15-16 (2015)

13. Y. Lin, L. Tu, H. Liu, W. Li, Renew. Sust. Energ. Rev., 55 (2016)

14. D. Mahto and A. Kumar, Journal of Industrial Engineering and Management, 1 (2008)

15. E. Citirik, Engineering Failure Analysis, 57 (2015)

16. A. Yunusa-Kaltungo, M.M. Kermani, A. Labib, Engineering Failure Analysis, 73 (2017)

17. R.E. McDermott, R.J. Mikulak, and M.R. Beauregard, The basics of FMEA (CRC Press, Boca Raton, FL, 2008). 